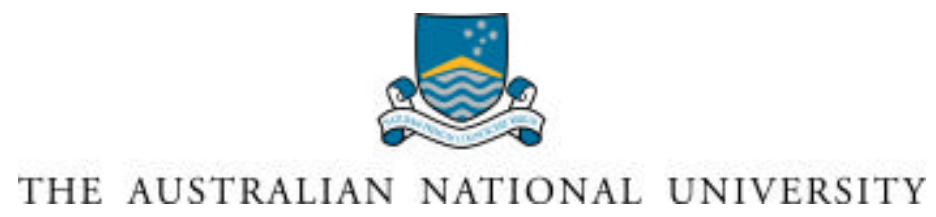

Working Paper Series in Finance 00-05

\title{
A COMPARISON OF MEASURES OF HEDGING EFFECTIVENESS: A CASE STUDY USING THE AUSTRALIAN ALL ORDINARIES SHARE PRICE INDEX FUTURES CONTRACT
}

\author{
T.J. Brailsford \\ K. Corrigan \\ R.A. Heaney \\ Department of Commerce \\ Australian National University
}

JEL Classification

G10, G13, G19

Keywords

Last revision date:

Hedge effectiveness; Hedging; Index futures

Contact author:

July 2000

Katherine Corrigan

Department of Commerce

The Australian National University

Canberra ACT 0200 AUSTRALIA

Telephone: 0262494855 (International +61 26249 4855)

Facsimile: 0262495005 (International +61 26249 5005)

Email: Katherine.Corrigan@anu.edu.au

The working paper series is for manuscripts in draft form. Comments are welcome and should be sent to the contact author. Please do not quote without permission.

(C) Copyright 2000 T.J. Brailsford, K. Corrigan and R.A. Heaney 


\title{
A COMPARISON OF MEASURES OF HEDGING EFFECTIVENESS: A CASE STUDY USING THE AUSTRALIAN ALL ORDINARIES SHARE PRICE INDEX FUTURES CONTRACT
}

\author{
Tim Brailsford \\ Katherine Corrigan \\ Richard Heaney \\ Department of Commerce \\ The Australian National University \\ Canberra, Australia
}

\begin{abstract}
Several techniques to assess the effectiveness of a hedge have been suggested in the literature. While these techniques hold theoretical appeal, there is little empirical evidence as to their effectiveness. This paper provides an empirical comparison of three measures of hedge effectiveness in the context of hedging market risk using the Australian All Ordinaries Share Price Index Futures contract. Specifically, the Markowitz (1959) portfolio standard deviation measure, the Howard and D'Antonio (1987) HBS measure and the measure suggested by Lindahl (1991) are applied to assess hedge effectiveness. The results indicate that the selection of the particular measure of hedge effectiveness has a considerable impact on the assessment of hedged portfolios. Further, the paper highlights problems that arise in applications of the Lindahl (1991) and Howard and D'Antonio (1987) measures.
\end{abstract}

\section{Acknowledgements}

We acknowledge the comments from staff in the Department of Commerce at the Australian National University, particularly the contributions of Grant Fleming. 


\section{$1 \quad$ Introduction}

Hedging has many definitions and the literature has adopted different approaches to defining the concept. Ghosh (1993b, p.743) observes that "the objective of hedging is to minimise the risk of the portfolio for a given level of return". Nance et al (1993, p.267) describe corporate hedging with derivatives as "the use of off-balance-sheet instruments ... to reduce the volatility of firm value". Duffie $(1989$, p.201) asserts that the essence of futures hedging is the "adoption of a futures position that, on average, generates profits when the market value of the given commitment is lower than expected, and generates losses when the market value of the commitment is higher than expected". Despite their different focus, the common theme linking these definitions is risk reduction, although some researchers, such as Sutcliffe (1993) and Pennings and Meulenberg (1997), have extended the purpose of hedging to include profit maximisation within the context of a portfolio.

The decision to hedge risk depends on a number of factors. First, the degree of risk aversion attributable to the investor influences their desire to hedge such that a risk-averse investor may be expected to hedge. According to Smith et al (1990), hedging has assumed increasing commercial importance over the last twenty years from the perspective of risk averse investors. More complex determinants of the decision to hedge, particularly relating to organisations such as banks, corporations and insurance companies, have also been considered in the literature. Smith and Stulz (1985) and Smith et al (1990) advance theories of hedging behaviour in which taxes, costs of financial distress and managerial risk aversion influence the decision to hedge. Generally, these suggestions have received empirical support. For instance, Nance et al (1993) provide empirical support for the theories of Smith and Stulz (1985). A survey conducted by Mian (1996) reveals that hedging activities are associated with economies of scale, although the evidence is mixed with regard to explanations of corporate hedging activity based on tax, capital 
market imperfections and contracting costs. An additional factor which may influence the decision to hedge is the availability of suitable derivative products.

Given that risk minimisation is a key purpose of hedging activity, it is necessary to be specific about the type of risk. Market risk is the risk that an adverse movement in the market as a whole will reduce the value of a financial investment. Collins and Fabozzi (1999) decompose market risk into interest rate risk, equity price risk, foreign exchange risk, commodity price risk, and basis risk. Hedging may reduce the exposure of fund managers, corporations and individual investors to such risk. In this paper, we focus on the market risk in the Australian equity market.

Generally, market movements are identified through the consideration of a share price index. In Australia, market movements are generally indicated by the Australian All Ordinaries Index (AOI). ${ }^{1}$ In 1983, the Sydney Futures Exchange introduced the Australian All Ordinaries Share Price Index Futures (SPI) contract, written over the AOI. ${ }^{2}$ The SPI contract, together with options written on the SPI, is the "primary equity derivative in Australia", according to official figures from the Sydney Futures Exchange. ${ }^{3}$

Share price index futures may be preferred to options written on share price index futures because the futures market is considerably more liquid than the options market, as evidenced by

\footnotetext{
${ }^{1}$ The Australian All Ordinaries Share Price Index is calculated using the market prices of approximately 330 of the largest companies listed on the Australian Stock Exchange. The index covers around 95\% of the total capitalisation of listed Australian stocks. The definition of this index changed in 2000, but the change occurred outside the sample period in this study.

${ }^{2}$ The SPI futures contract unit is calculated by multiplying the AOI value by \$A25. Delivery of the SPI futures occurs in March, June, September and December, up to eighteen months ahead. Trading ceases on the last business day of the contract month, and settlement occurs through the Sydney Futures Exchange Clearing House on the second business day following the last permitted day of trading. As there is no tangible commodity to deliver, settlement is always made in cash and the settlement price is the closing quotation for the All Ordinaries Share Price Index on the last day of trading, calculated to a single decimal place.

${ }^{3}$ Other non-equity derivatives, including 90-Day Bank Accepted Bill Futures and 3-Year Treasury Bond Futures, are traded more heavily than the equity derivatives. However, of the equity derivatives traded in Australia, the SPI futures and options are the most heavily traded.
} 
the relative annual SFE floor trading volume of the equivalent Australian derivatives. ${ }^{4}$ Further, Ghosh (1993b) notes that generally, index futures are favoured as a hedging vehicle because of their speed and lower transaction costs, including the bid-ask spread and brokerage commissions. Empirical evidence presented by Benet and Luft (1995) and Hsin, Kuo and Lee (1994) supports the use of futures over options for hedging, given transactions costs and market frictions.

Hedging market risk is of considerable commercial importance. In a recent paper, Walter (1999, p.1) asserts that "[f]unds under institutional management are massive and growing rapidly, particularly as part of the resolution of pension pressures". He estimates that on a global scale, the global total of assets under management in 1997 was estimated at close to $\$ 30$ trillion. In Australia, the assets of managed funds, and in particular superannuation funds, have increased considerably over the last seven years, from \$A267,333 million to \$A581,170 million. ${ }^{5}$ These funds may have significant exposure to market risk, and may choose to use share price index futures contracts to reduce the risk of losses on their portfolios.

To implement a hedge, it is necessary to determine the appropriate hedge ratio. Hull (1997, p.35) defines a hedge ratio as the "ratio of the size of the position taken in futures contracts to the size of the exposure". Subsequent to the estimation of the hedge ratio, there are a variety of techniques available to assess the effectiveness of the hedge. Two main approaches to hedge effectiveness have emerged in the literature, namely measures which address the risk reduction aspect of the hedge, and measures which incorporate aspects of both risk and return. The selection of measures of effectiveness is likely to impact on the assessment of hedge effectiveness. However, empirical evidence on this issue is scarce.

\footnotetext{
${ }^{4}$ For example, in 1998 the annual trading volume in All Ordinaries Share Price Index futures was 3,280,512 contracts compared to the annual trading volume in SPI Options of 832,227 contracts.

${ }^{5}$ Data on managed as sets was obtained from the Reserve Bank of Australia Bulletin, September 1999. Data from June of each year are used.
} 
This paper examines the application of different measures of hedging effectiveness when hedging market risk using the Australian All Ordinaries Share Price Index Futures contract. Hence, the contribution of the paper is to provide comparative evidence on the performance of various hedge effectiveness measures. This contribution is of practical importance given the need for investors, treasurers and fund managers to determine the effectiveness of hedging activities, and adjust their strategies accordingly. Clearly, accurate measures of hedge effectiveness are required for effective decision-making.

Section Two of the paper provides a description of the theoretical framework, and a discussion of the relevant literature. The research method is presented in Section Three. Section Four provides a description of the data. Results and analysis are presented in Section Five. Finally, conclusions are provided in Section Six, accompanied by suggestions for further research.

\section{Prior Literature}

\subsection{Theoretical Framework: Mean-Variance Portfolio Theory}

The theoretical framework most commonly applied to the evaluation of hedge ratios is the meanvariance theory of portfolio selection. According to Markowitz (1959), all investors share the objective of maximisation of expected return for a given level of risk, or alternatively minimising risk for a given expected return. Johnson (1960) provides a theoretical analysis of hedging using commodity futures, based on the concept that hedgers are motivated by the desire to obtain an optimum combination of expected return and variance as determined by their utility functions. Stein (1961) also applies mean-variance portfolio theory to hedging using commodity futures contracts.

However, the mean-variance portfolio approach suffers from a number of limitations arising from the assumptions on which it is founded. General limitations are discussed in detail 
elsewhere, by authors including Marshall and Herbst (1992), Kolb and Okunev (1993). Further, Marshall and Herbst (1992) identify specific limitations within the context of futures hedging. They argue that the mean-variance framework ignores the fact that futures positions are taken without initial investment. The mean-variance framework is a single period model, while futures hedging is multi-period. Further, short futures positions should be treated as having positive portfolio weights, given positive margin requirements, but they are treated as having negative weights under the Markowitz approach.

Alternative hedging frameworks, such as the Mean-Gini approach, have been proposed. While the theoretical base underlying Mean-Gini is sound, there have been on-going practical problems associated with the calculation of the extended Mean-Gini coefficient. ${ }^{6}$ Moreover, this technique does not appear to be widely used in practice. Until alternative techniques such as Mean-Gini become more amenable to empirical application, the mean variance theory will continue to dominate because of its simplicity, intuitive appeal, and ease of calculation.

Within the mean-variance framework, the criteria for assessment of the effectiveness of a hedge depends on the objective of the hedge. There are two main approaches to the assessment of hedging effectiveness. The first, and more traditional view is that hedging is aimed exclusively at risk minimisation. Proponents of the second approach consider hedging to be aimed at both risk minimisation and return maximisation. Both approaches attribute behaviour and the degree of success of a hedge to the motivating effects of risk and return.

\subsection{Risk Reduction Measures of Effectiveness}

Although basis risk prevents the existence of a perfect hedge, the risk may be minimised through hedging. Indeed, Working (1953, p.326, original emphasis) asserts that "hedging in commodity

\footnotetext{
${ }^{6}$ Discussions of the Mean-Gini framework are provided by Kolb and Okunev (1993), Shalit (1995), and more recently by Lien and Shaffer (1999).
} 
futures involves the purchase and sale of futures in conjunction with another commitment, usually in the expectation of a favourable change in the relation between spot and futures prices." In short, hedging may be viewed as speculation on the basis. In the spirit of Working (1953), Castelino (1992, p 199) asserts that the "minimum-variance hedge ratio ... minimises risk for the level of return implied by the basis".

Ederington (1979) is credited with synthesising the work of Working (1953, 1962), Johnson (1960) and Stein (1961) to create a measure of hedging effectiveness based exclusively on risk reduction. His technique involves the consideration of the coefficient of determination, also known as the unadjusted $\mathrm{R}^{2}$ statistic from the hedge ratio regression. Ederington (1979) measures hedging effectiveness as the percent reduction in variability. Ederington's (1979) technique applies to hedge ratios calculated using ordinary least squares (OLS) regressions, and only remains valid when the data satisfies the assumptions of OLS. Ederington's technique has been applied and discussed by Franckle (1980), Hill and Schneeweis (1981), Gjerde (1987), Herbst, Kare and Caples (1989), and Pennings and Meulenberg (1997).

However, the applicability of Ederington's (1979) effectiveness measure to more complex hedge ratio estimation models is questionable. For instance, Herbst, Kare and Caples (1989, p.90) note that Ederington's (1979) measure must be "interpreted with caution" when applied to BoxJenkins ARIMA models. Logically, this comment extends to the assessment of other hedge ratio estimation techniques including error correction models, given that the original measure was not designed to assess the hedge ratios obtained using such models.

A more general measure of hedge effectiveness may be drawn directly from Markowitz's (1959) theory, namely the reduction in standard deviation of portfolio returns associated with a 
hedge. This measure has the advantage of applying regardless of the estimation technique employed to obtain the hedge ratio. Further, it is easily interpreted and has intuitive appeal.

\subsection{Risk-Return Measures of Effectiveness}

In a widely cited paper, Howard and D'Antonio (1984) define hedging effectiveness in terms of both risk and return, rather than exclusively in terms of risk reduction. Drawing on the work of Anderson and Danthine (1981), Black (1976), Dale (1981), Working (1953), Stein (1961) and Johnson (1960), Howard and D'Antonio (1984) develop the following measure of hedging effectiveness: ${ }^{7}$

$$
H E=\frac{\theta_{h}}{\theta_{s}}
$$

where

$H E=$ hedge effectiveness

$\theta_{h}=$ Sharpe ratio of the hedged portfolio

$\theta_{s}=$ Sharpe ratio of the unhedged portfolio

and

$$
\theta=\frac{\left(R_{p}-i\right)}{\sigma_{p}}
$$

where

$$
\begin{aligned}
& R_{p}=\text { expected return on the portfolio }^{8} \\
& i=\text { risk free rate of return } \\
& \sigma_{p}=\text { standard deviation of return for the portfolio }
\end{aligned}
$$

However, the Howard and D'Antonio (1984) model is potentially flawed, and subsequent researchers have arguably improved it. Chang and Shanker (1987) demonstrate that the second order condition of Howard and D'Antonio (1984) is incorrect, and specifically that it is not

\footnotetext{
${ }^{7}$ Sharpe (1994) provides a useful discussion of the intuition underlying the Sharpe ratio used in the hedge effectiveness measure.

${ }^{8}$ Expected return is defined in the tradition of Markowitz (1959) as $E\left(R_{p}\right)=\sum_{i=1}^{n} w_{i} \cdot E\left(R_{i}\right)$ where $E\left(R_{p}\right)=$ expected return on portfolio, $E\left(R_{i}\right)=$ expected return on asset i, and $w_{i}=$ weighting of asset $\mathrm{i}$ in the portfolio. 
necessary for the difference between the return on the unhedged portfolio and the return on the risk free rate to be greater than zero. Further, Chang and Shanker (1987) demonstrate that the Howard and D'Antonio (1984) measure produces inconsistent results. They propose a revised measure of effectiveness, $H E_{1}$, as follows:

$$
H E_{1}=\frac{\theta_{h}-\theta_{s}}{\left|\theta_{s}\right|}
$$

where the parameters are as defined previously.

Howard and D'Antonio (1987, p.378) recognise that their original second order conditions are incorrect, but argue that "we do not think that the situation in which $\mathrm{r}_{\mathrm{s}}$ is less than the risk-free return is very interesting", where $r_{s}$ is defined as the return on the unhedged portfolio. However, this view may not be sustainable, in light of the evidence presented later in this paper. Nevertheless, Howard and D'Antonio (1987, p .78) concede that when this situation occurs, or when the difference between $r_{s}$ and the risk-free rate is small or zero, the $H E$ model "yields some very confusing results". They demonstrate the deficiencies of both the $H E$ model and the Chang and Shanker (1987) $H E_{1}$ model using numerical examples. ${ }^{9}$ Howard and D'Antonio (1987) advance an arguably superior model of hedge effectiveness, $H B S$, as follows:

$$
H B S=\frac{\left(i+\theta_{h} \cdot \sigma_{s}-r_{s}\right)}{\sigma_{s}}
$$

where the parameters are as defined previously.

Lindahl (1991) criticises the measures of Howard and D'Antonio $(1984,1987)$ and Chang and Shanker (1987) as having "serious drawbacks". Lindahl (1991) states that the $H E_{1}$ and $H B S$ measures cannot be used to evaluate the effectiveness of stock index futures hedges because the measures decrease as basis risk approaches zero, and at the limit, $\theta_{h}=\theta_{s}$ and both $H E_{1}$ and

\footnotetext{
${ }^{9}$ Kuo and Chen (1995) and Satyanarayan (1998) provide further criticisms and simplifications of the derivations of the Howard and D'Antonio $(1984,1987)$ models.
} 
$H B S$ equal zero. She suggests a new measure, based on the idea that when stock index futures are priced in equilibrium, fully hedged portfolios earn the risk free rate of return.

Other models of hedging effectiveness have been advanced including Pennings and Meulenberg (1997) and Gjerde (1987). For instance, Gjerde (1987) presents two measures of hedge effectiveness, including a risk-return measure based on linear mean-variance preferences, which incorporates transaction costs and margins. Pennings and Meulenberg's (1997) measure focuses on the "hedging service" of the futures contract rather than the performance of the hedged portfolio.

Detailed commentary on the relative empirical merits of different measures is scarce. In empirical work, a single measure of hedging effectiveness is generally selected. Benet and Luft (1995) provide an exception, although they apply measures shown to be flawed, including Howard and D'Antonio (1984), rather than the most recent versions (HBS). Moreover, the Lindahl (1991) measure has not been applied empirically or compared with other measures. Given the lack of evidence on this topic, this paper seeks to examine the impact of the selection of effectiveness measure on the assessment of a hedge.

\section{Research Method}

\subsection{Hedge Models}

First, we define the return on a hedged portfolio as follows:

$$
R=\frac{\left(s_{1}-s_{0}\right)-h \cdot\left(f_{1}-f_{0}\right)}{s_{0}}
$$

where

$$
R=\text { return on hedged portfolio }
$$

$s_{0}=$ spot price at end of time 0

$f_{0}=$ futures price at end of time 0

$s_{l}=$ spot price at end of time 1

$f_{l}=$ futures price at end of time 1

$h=$ hedge ratio 
There are a variety of methods available to calculate hedge ratios. As Castelino (1992, p.188) observes, there is a "distinct bias in favour of regression analysis". The most simple technique is the price levels regression, as follows:

$$
S_{t}=\alpha+\beta \cdot F_{t}+\varepsilon_{t}
$$

where

$S_{t}=$ spot price at time $\mathrm{t}$

$F_{t}=$ futures price at time $\mathrm{t}$

$\beta=$ hedge ratio

Engle and Granger (1987) advance a method for determining whether time series are cointegrated. If cointegration is detected, an error correction model can be used to cater for both short run and long run impacts. An error correction model should produce hedge ratios which exhibit superior effectiveness, relative to ratios produced by traditional regression models, as the former is designed to improve the specification of the latter models. The optimal hedge ratio from an error correction model is the coefficient $\beta$ from the following equation:

$$
\Delta S_{t}=\alpha \cdot u_{t-1}+\beta . \Delta F_{t}+\sum_{i=1}^{m} \delta_{i} \Delta F_{t-i}+\sum_{j=1}^{n} \phi_{j} \Delta S_{t-j}+\varepsilon_{t}
$$

where

$\Delta S_{t}=$ change in spot price at time $\mathrm{t}$

$\Delta F_{t}=$ changes in futures price at time $\mathrm{t}$

$\beta=$ hedge ratio

$\Delta F_{t-i}=$ lagged futures terms

$\Delta S_{t-j}=$ lagged spot terms

$u_{t}=$ residuals from the regression of spot and futures levels

The residuals, $u_{t}$, are collected from the price levels regression in equation (6) above, and used as inputs in the error correction model.

Broadly, there are two methods used to assess the effectiveness of a hedge ratio - in-sample and out-of-sample tests. As observed by de Jong et al (1997), most empirical studies on hedging utilise in-sample test procedures, which are based on the assumption that hedging effectiveness 
can be measured using the same data relied on in the calculation of the hedge ratio. This assumption is highly questionable, given that practitioners do not have the luxury of waiting until the end of the hedge period to determine the most effective hedging technique. Moreover, such a technique invokes criticisms of data-mining.

In contrast, out-of-sample tests provide a more realistic means to assess hedge effectiveness. Out-of-sample tests entail the assessment of the hedge ratio in a period of time subsequent to the estimation period, namely the hedge period. The first period of data is used to calculate the hedge ratio, which is then assessed using the second period of data. All measures of hedging effectiveness in this paper are employed using out-of-sample data.

\subsection{Standard Deviation Method}

The most basic measure of hedge effectiveness is the reduction in portfolio standard deviation associated with the hedge, calculated as follows:

$$
\sigma_{p}=\sqrt{\frac{1}{n} \sum_{i=1}^{n}\left(R_{i}-E\left(R_{i}\right)\right)^{2}}
$$

where

$$
\begin{aligned}
& \sigma_{p}=\text { portfolio standard deviation } \\
& R_{i}=\text { return on asset } \mathrm{i} \\
& E\left(R_{i}\right)=\text { expected return on asset } \mathrm{i} \\
& n=\text { number of observations }
\end{aligned}
$$

The greater the reduction in risk, as measured by the difference in the standard deviations of the unhedged and hedged portfolios, the greater the effectiveness of the hedge. 


\subsection{Howard and D'Antonio's (1987) Method}

Howard and D'Antonio's (1987) refined measure of hedging effectiveness is:

$$
H B S=\frac{\left(i+\theta_{h} \cdot \sigma_{s}-r_{s}\right)}{\sigma_{s}}
$$

where

$i=$ risk-free rate

$\theta_{h}=$ Sharpe ratio for hedged portfolio

$\sigma_{S}=$ standard deviation of unhedged spot portfolio

$r_{s}=$ return on unhedged spot portfolio

Through the rearrangement of equation (9), it can be shown that the $H B S$ is simply the difference between the Sharpe Ratios for the hedged and unhedged portfolios. The advantage of the $H B S$ measure is that it encapsulates both risk and return in a single figure.

A negative value for the $H B S$ measure indicates that the excess return per unit of risk for the unhedged portfolio exceeds that of the hedged portfolio. In that case, the mean-variance investor should elect not to hedge. A $H B S$ value of zero indicates that the hedged and unhedged portfolios are associated with identical excess returns per unit of risk, meaning that the investor is indifferent to the hedge. However, the investor should not hedge in this case because they would incur transactions costs without receiving any benefits. A positive value of $H B S$ indicates that the hedged portfolio outperforms the unhedged portfolio on the basis of excess return per unit of risk. Therefore, the $H B S$ measure must be positive before the mean-variance investor receives any benefit from the hedge. Superior performance among different hedged portfolios is indicated by the highest relative $H B S$ measure. 


\subsection{Lindahl's (1991) Method}

As with the Howard and D'Antonio method, Lindahl's (1991) method takes into account aspects of both risk and return. Lindahl's (1991) measure can be stated as follows:

Lindahl's (1991) mean:

$$
M_{L}=\frac{1}{n} \sum_{j=1}^{n}\left(R_{h}-i\right)
$$

Lindahl's (1991) standard deviation:

$$
\sigma_{L}=\sqrt{\frac{1}{n} \sum_{j=1}^{n}\left(\left(R_{h}-i\right)-E\left(R_{h}-i\right)\right)^{2}}
$$

where

$M_{L}=$ Mean of the difference between the return on the hedged portfolio and the riskfree rate of return

$\sigma_{L}=$ Variance of the difference between the return on the hedged portfolio and the risk-free rate of return

$R_{h}=$ return on the fully hedged portfolio in time period $\mathrm{t}$

$i=$ risk-free rate for time period $\mathrm{t}$

$n=$ number of observations

In Lindahl's (1991, p.407) words, "the closer $M_{L}$ is to zero and the smaller the $\sigma_{L}$, the more effective the hedge".

\section{DATA}

\subsection{Sample and Data Sources}

This paper uses the Australian equity market as the basis for the case study. The spot market is proxied by the Australian All Ordinaries Share Price Index (AOI) while the hedge instrument is the All Ordinaries Share Price Index Futures contract (SPI). Daily data are used over the period 17 July 1990 to 9 June $1999 .^{10}$

Both the Howard and D'Antonio (1987) and the Lindahl (1991) measures require the risk-free rate of return. Australian interbank rates of interest are employed in this study. Because the

\footnotetext{
${ }^{10}$ Data on the AOI were obtained from Datastream while data on the SPI were taken from the Sydney Futures Exchange website
} 
interbank rates are available weekly, monthly, three monthly, six monthly and yearly, close matching of the risk-free interest rate and the hedge period is achieved. Further, interbank rates are drawn from a liquid market, although there is a small premium applied to these rates compared to the Australian Three Month Treasury Bill. ${ }^{11}$

Outliers in the data were identified and cross-checked against data provided by the Australian Financial Review. It is assumed that futures roll-over occurs five trading days prior to expiry, where expiry is defined as the date of settlement, which occurs two business days subsequent to the last day of trading. In collecting data, a trading day is defined as one on which floor trading occurs at the Sydney Futures Exchange. ${ }^{12}$ The futures price level on any day is defined as the natural logarithm of the last traded SPI floor price on that day. Similarly, the spot level is the natural logarithm of the daily closing AOI value. Price changes are taken as the difference in the natural logarithm of the daily last price across successive days.

\subsection{Descriptive Statistics}

Descriptive statistics for the All Ordinaries Share Price Index and the All Ordinaries Share Price Index Futures contract are provided in Table 1. In addition, descriptive statistics are presented for the proxies of the risk-free rate of interest, specifically the 1-week, 1-month, 3-month, 6 month and 1-year interbank interest rates.

\section{INSERT TABLE ONE}

The statistics indicate that the AOI data and the SPI futures data do not conform to normality. The interest rates are also non-normal and fluctuate over the sample period within a range of nominal rates from $4.17 \%$ to $10.7 \%$.

\footnotetext{
${ }^{11}$ The selection of interbank rates is discussed in more detail in Section 5.3.

${ }^{12}$ Given that this paper focuses on hedging activity with matched futures and spot data, controlling for day-of-the-week effects is not of interest.
} 


\subsection{Cointegration Tests}

The method of Engle and Granger (1987) is employed to test for cointegration between the futures and spot series. First, the augmented Dickey-Fuller (ADF) test for unit roots is applied to determine whether the variables are stationary. The results indicate that each price level series is non-stationary, but that first differences are stationary. Specifically, the ADF test provides values of -3.62 and -3.52 for the AOI and SPI series respectively, with both values violating the $1 \%$ critical value of $-3.96 .^{13}$ The ADF tests on first differences have values of -7.07 and -7.54 for the spot and futures series respectively. Thus, the first condition for cointegration is established, namely the existence of an I(1) relationship in each of the futures and spot series.

Second, application of the Augmented Dickey-Fuller test to the residuals from the regression between the natural logs of the futures and spot indicates that the series are cointegrated. Specifically, the ADF test provides a statistic of -5.45 , which is smaller than the critical value of $-4.32 .{ }^{14}$ Based on these results, an error correction model is used to calculate hedge ratios.

\section{$5 \quad$ RESULTS AND ANALYSIS}

\subsection{Hedge Ratio Estimation ${ }^{15}$}

A representative example of the hedge ratios is presented in Table 2 and is used in the following discussion. The table contains the hedge ratios estimated over eight different time periods, and descriptive statistics accompanying each hedge ratio.

\section{INSERT TABLE 2}

In short, results from the error correction model appear to comply with the assumptions of OLS regression. The R-square statistics are high, indicating good model fit, consistent with prior

\footnotetext{
${ }^{13}$ Critical values are obtained from Davidson and MacKinnon (1993).

${ }^{14}$ The finding of cointegration between the spot and futures series is not surprising. Previous empirical evidence, such as Stoll and Whaley (1990), indicates a close link between the futures and spot markets. Further, Ghosh (1993a, 1993b), Wahab and Lashgari (1993), Pizzi, Economopoulos and O'Neill (1998), and Lien and Luo (1993) find that the S\&P 500 index and futures markets are cointegrated.

${ }^{15}$ Complete results for hedge ratios and accompanying descriptive statistics are available from the contact author on request.
} 
empirical evidence (Ghosh (1993b)). Given the Jarque-Bera asymptotic LM Normality statistics, it is not possible to reject normality of the residuals. Heteroscedasticity is not evident in the residuals associated with the error correction model, providing empirical support for the selection of the error correction models of hedge ratio estimation for this data set, as opposed to the GARCH models advocated by Kroner and Sultan (1993) and Park and Switzer (1995).

\subsection{Effectiveness of Hedge Ratios}

In this section, the impact of changes in estimation period on hedge effectiveness is examined using the different measures of effectiveness. ${ }^{16}$ Further results are examined to determine if the results are consistent between long- and short-term hedges.

Results using the Markowitz (1959) portfolio standard deviation measure of effectiveness, the Howard and D'Antonio (1987) HBS measure, the Lindahl (1991) mean and Lindahl (1991) standard deviation measures are presented in Table 3. The negativity of the $H B S$ and Lindahl mean results is discussed in detail in a subsequent section. The rankings derived from the results in Table 3 are provided below, in Table 4 . The rankings are averaged across the test periods and an overall ranking is provided in the last row of Table 4.

\section{INSERT TABLES 3 AND 4}

The portfolio standard deviation measure indicates that, on average, the most effective hedge ratios are produced using longer estimation periods such that the most effective hedges are obtained using 240 days, 120 days and 60 days, in that order. The $H B S$ measure of Howard and D'Antonio (1987) indicates the reverse, as does the Lindahl mean. That is, the most effective hedge ratios are produced using shorter estimation periods. The Lindahl standard deviation indicates that the most effective estimation period is 120 days, followed by 240 days, then 60

\footnotetext{
${ }^{16}$ As a precursor to the examination of the impact of estimation period on hedge effectiveness, the impact of the estimation period on the hedge ratio levels was examined (results not reported). The hedge ratios generally increase as the estimation period increases, suggesting that the estimation period may influence hedge effectiveness.
} 
days. Thus, the introduction of the consideration of returns into the evaluation of hedge effectiveness using the $H B S$ measure reverses the rankings obtained by considering only risk. The rankings produced by the Lindahl mean provide additional support for attributing the reversal in ranks to the consideration of returns, given the mathematical relationship between the $H B S$ and Lindahl mean calculations. The Lindahl standard deviation and the ordinary standard deviation of the portfolio produce similar but not identical rankings, indicating that the introduction of the risk-free rate in the Lindahl measure alters the assessment of the risk alone in hedging to some extent.

The key result from Tables 3 and 4 is that the various hedge effectiveness measures produce different results across different estimation periods. Hence, reliance upon one measure alone may lead to a different conclusion in assessing the hedge.

As standard deviation increases, mean-variance investors require greater returns to compensate for increased risk. Thus, it is expected that an inverse relationship will exist between the rankings obtained using the Lindahl mean and Lindahl standard deviation measures. This is generally supported by the results above, in that the lowest ranking Lindahl standard deviation is associated with the highest ranking Lindahl mean results. According to Lindahl (1991), these two measures are to be read together, to arrive at an overall conclusion as to hedge effectiveness. However, it is impossible to obtain an overall ranking using both measures unless either risk or return is accorded priority. This is an inherent flaw in the Lindahl (1991) measure.

Tables 3 and 4 assess the hedge of a relatively long out-of-sample hedge period of 240 days. To examine the sensitivity of these results to a short-term hedge period, Table 5 presents the rankings from out-of-sample hedge periods of 5 days. Again the impact of varying the estimation period is apparent with resultant different rankings across the measures. The Markowitz 
standard deviation measure indicates that the 240 day estimation period produces the hedge ratio which results in a hedged portfolio with the least risk. The second-best risk reducing hedge ratio is obtained using the estimation period of 120 days, and the third-best hedge is obtained using an estimation period of 60 days. This is consistent with the longer hedge period rankings in Table 4. As expected, the Lindahl standard deviation measure produces rankings that are identical to those associated with the Markowitz standard deviation measure. The HBS rankings are also consistent between the long and short hedge periods. However, a further problem emerges from this analysis. The Lindahl mean measure produces the same ranking as the Lindahl standard deviation measure, which suggests that risk is decreasing as return is increasing, contrary to expectations.

\section{INSERT TABLE 5}

In summary, both the estimation period and hedge period impact on the hedge effectiveness rankings. Thus, the measurement of hedge effectiveness using the Markowitz portfolio standard deviation measure, the Howard and D'Antonio (1987) HBS measure, or the Lindahl (1991) measure will alter the relative rankings of hedges.

Of the measures which incorporate both risk and return, the $H B S$ measure of Howard and D'Antonio (1987) is preferred to the dualpronged measure of Lindahl (1991) because the Lindahl mean and standard deviation measures produce inconsistent rankings and introduce the additional difficulty of formulating an appropriate decision rule to arrive at a single ranking. Further, despite the commentary provided by Lindahl (1991), her measure takes into account the same factors addressed by the $H B S$ measure. The Lindahl mean is simply the Sharpe ratio on which $H B S$ is based, altered to remove the standard deviation, which is taken into account in Lindahl's second measure. The advantage of the $H B S$ measure is that it synthesises information on risk and return into a single measure, facilitating easy ranking. However, the application of the $H B S$ measure is also subject to difficulties, as discussed below. 


\subsection{The Risk Free Rate and the Decision to Hedge}

Howard and D'Antonio (1987, p.378) comment that "the market participant on which we are focusing will no doubt be risk-averse. Since the spot asset is risky and since the participant is risk averse, it is very unlikely that he (sic) will be interested in holding an asset with a negative risk premium (i.e., $\mathrm{r}_{\mathrm{s}}-\mathrm{i}<0$ )". This comment is problematic in practice as demonstrated below. A striking feature of the results of $H B S$ and the Lindahl mean measures is their consistent negative return over the ten-year period of study. This occurs because the risk free rate exceeds the rates of return on both the hedged and unhedged portfolios. Thus, the data indicate that the situation described is of practical importance. For instance, an examination of a representative sample of results using the Howard and D'Antonio (1987) HBS measure provided in Table 6 illustrates that the return on both the spot and the hedged portfolios fall below the risk free rate in a large number of cases. This is not attributable to the selection of the risk free proxy as the premium on the Interbank rate over the 3-Month Treasury Bill was very small over the sample period. $^{17}$

Table 6 indicates whether the hedged portfolio "outperforms" the unhedged portfolio, according to the $H B S$ measure. Specifically, if the hedged portfolio outperforms the unhedged portfolio, the HBS measure is positive, and the investor is advantaged by the hedge. If the $H B S$ measure is negative, the unhedged portfolio "outperforms" the hedged portfolio, and the hedge disadvantages the investor. From Table 6, in all cases but one, the hedge was disadvantageous.

\section{INSERT TABLE 6}

\footnotetext{
${ }^{17}$ The average of the difference in daily effective Interbank rates (each of the 1-week, 1-month, 3-month, 6month and 1-year rates) and the daily effective 3-month Treasury Bill rate was calculated over the sample period. To provide clearer intuition, the results were then annualised by multiplying by 252 , which is the average number of trading days in one year over the sample. The largest annual mean difference between Interbank and 3-month Treasury Bill rates was only 0.32\%, associated with the 1-year Interbank rate (the mean daily difference between the 1-year Interbank rate and the Treasury Bill rate was $0.0013 \%$ ).
} 
In short, the mean-variance investor will choose not to hedge when the $H B S$ measure is negative. This is of particular concern given the negativity of the majority of results using the $H B S$ measure. According to the $H B S$ results, the investor should not have hedged over the ten years investigated here. However, this is clearly inconsistent with market practice. The Sydney Futures Exchange observes that the ratio of open interest to volume in the SPI contract provides strong evidence that trading in the contract is primarily driven by hedgers. Indeed, the Sydney Futures Exchange promotes this contract as exhibiting one of the highest ratios of open interest to volume relative to all the major stock indices around the world. That hedgers form a large proportion of those participating in the market for that contract is hardly surprising given that the contract was created with a view to satisfying the need of hedgers to manage price risk.

Given that the trading reality reveals that hedging is occurring over the period of study, despite the results provided by $H B S$ measure indicating that hedging should not occur, and assuming that investors are rational, one conclusion is that the $H B S$ measure is flawed. In particular, the measure fails to capture important aspects of hedging behaviour and effectiveness, other than the pure hedge component of the demand for futures. Other reasons for the decision to hedge, discussed briefly earlier include the costs of financial distress, taxation considerations, industry practices, agency costs and managerial compensation contracts which may induce managers to make "sub-optimal" hedges. A less plausible explanation may be lack of understanding on the part of hedgers, as perhaps in cases such as Metallgesellschaft (Edwards and Canter (1995), Culp and Miller (1995), Pirrong (1997)). A final explanation is of course that the underlying hedge models used here are imperfect themselves. However, this research is inevitably one that involves the "joint test" problem. 


\section{CONCLUSION}

This study compares measures of hedging effectiveness in the context of hedging market risk using the Australian All Ordinaries Share Price Index Futures contract. The framework applied in the study of the hedging component of demand for futures contracts is the mean-variance portfolio theory of Markowitz (1959).

The results reveal that the assessment of hedge effectiveness alters, depending on the measure employed. The rankings produced by the various measures are sensitive to both the length of the estimation period and the test period. This finding occurs despite the fact that each measure falls within the Markowitz (1959) mean-variance framework. Specifically, the relative ranking of the hedges is affected by the selection of the reduction in portfolio standard deviation measure of effectiveness, the Howard and D'Antonio (1987) HBS measure, or the Lindahl (1991) measure. This is an important finding for practitioners who need to consider hedge effectiveness when assessing hedge performance.

Further, evidence is provided that the theoretically appealing measures of Howard and D’Antonio (1987) and Lindahl (1991) suffer from flaws on empirical application. The empirical application of the Lindahl (1991) measure has not been attempted previously. Similarly, while the earlier model of Howard and D'Antonio (1984) has been applied by Benet and Luft (1995), the Howard and D'Antonio (1987) model has not been employed empirically. Therefore, the results should be of considerable interest.

The analysis in this paper suggests several avenues for further research. One such avenue is the development of a new measure of effectiveness that overcomes the problems associated with existing measures. More complex measures of effectiveness, such as Gjerde's (1987) measure, which incorporates transactions costs and margin calls, were not examined here, but may 
provide alternatives. For instance, a measure could be designed that incorporates taxes in addition to transactions costs. Alternatively, a satisfactory method of reconciling the ranks produced by the two prongs of the Lindahl (1991) measure into a single overall rank would be useful. Alternative hedging frameworks such as the Mean-Gini framework warrant further research. In particular, the operationalisation of Mean-Gini theory requires considerable work, which may be justified to the extent that the theory avoids some difficulties associated with the mean-variance framework. 
Table 1

Descriptive Statistics for Daily All Ordinaries Share Price Index Levels and Changes, Daily All Ordinaries Share Price Index Futures Levels and Changes, and Daily Nominal Interbank Interest Rates

\begin{tabular}{|c|c|c|c|c|c|c|c|c|c|}
\hline & & Mean & Median & $\begin{array}{l}\text { Standard } \\
\text { Deviation }\end{array}$ & Skewness & $\begin{array}{c}\text { Excess } \\
\text { Kurtosis }\end{array}$ & Maximum & Minimum & $\begin{array}{c}\text { Durbin } \\
\text { Watson }\end{array}$ \\
\hline \multirow{3}{*}{$\begin{array}{l}\text { AOI } \\
\text { Spot }\end{array}$} & Level, S & 2073.32 & 2074.1 & 465.36 & 0.1799 & -1.0182 & 3145.2 & 1204.52 & 0.0015 \\
\hline & Level, Ln(S) & 7.6112 & 7.6373 & 0.2287 & -0.1350 & -1.0670 & 8.0536 & 7.0938 & 0.0013 \\
\hline & Change, Ln(S) & 0.0003 & 0.0003 & 0.0083 & -0.2817 & 4.7886 & 0.0607 & -0.0745 & 1.8477 \\
\hline \multirow{3}{*}{$\begin{array}{l}\text { SPI } \\
\text { Futures }\end{array}$} & Level, F & 2081.6 & 2081 & 467.06 & 0.1759 & -1.0216 & 3153 & 1190 & 0.0023 \\
\hline & Level, Ln(F) & 7.6151 & 7.6406 & 0.2287 & -0.1387 & -1.0663 & 8.0561 & 7.0817 & 0.0021 \\
\hline & Change, Ln(F) & 0.0001 & 0.0000 & 0.0104 & -0.0044 & 2.7721 & 0.0733 & -0.0648 & 2.0579 \\
\hline \multirow{5}{*}{$\begin{array}{l}\text { Interbank } \\
\text { Rates }\end{array}$} & 1 Week Rate & 6.19 & 5.80 & 1.41 & 0.94 & 0.40 & 10.70 & 4.19 & 0.003 \\
\hline & 1 Month Rate & 6.20 & 5.85 & 1.38 & 0.93 & 0.37 & 10.62 & 4.73 & 0.002 \\
\hline & 3 Month Rate & 6.21 & 5.85 & 1.38 & 0.84 & -0.01 & 10.52 & 4.60 & 0.002 \\
\hline & 6 Month Rate & 6.26 & 5.92 & 1.42 & 0.80 & -0.22 & 10.43 & 4.57 & 0.002 \\
\hline & 1 Year Rate & 6.45 & 6.23 & 1.46 & 0.73 & -0.32 & 10.47 & 4.17 & 0.005 \\
\hline
\end{tabular}

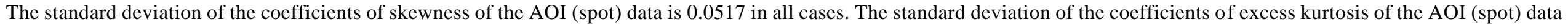

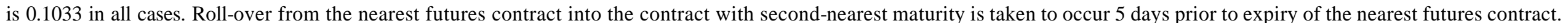

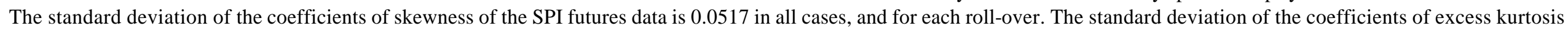

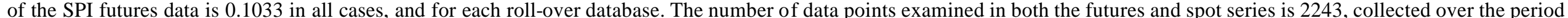

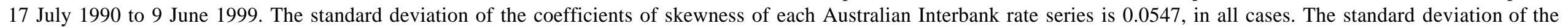
coefficients of excess kurtosis of each Interbank rate series is 0.1093 , in all cases. 
Table 2

Hedge Ratios and Accompanying Descriptive Statistics, Calculated using the Error Correction Model

\begin{tabular}{|c|c|c|c|c|c|c|c|c|}
\hline & $\begin{array}{c}\text { Test } \\
\text { Period } \\
1 \\
\end{array}$ & $\begin{array}{c}\text { Test } \\
\text { Period } \\
2 \\
\end{array}$ & $\begin{array}{c}\text { Test } \\
\text { Period } \\
3 \\
\end{array}$ & $\begin{array}{c}\text { Test } \\
\text { Period } \\
4 \\
\end{array}$ & $\begin{array}{c}\text { Test } \\
\text { Period } \\
5 \\
\end{array}$ & $\begin{array}{c}\text { Test } \\
\text { Period } \\
6 \\
\end{array}$ & $\begin{array}{c}\text { Test } \\
\text { Period } \\
7 \\
\end{array}$ & $\begin{array}{c}\text { Test } \\
\text { Period } \\
8 \\
\end{array}$ \\
\hline Start Date & $04 / 04 / 91$ & $03 / 04 / 92$ & $02 / 04 / 93$ & $06 / 04 / 94$ & $04 / 04 / 95$ & $02 / 04 / 96$ & $04 / 04 / 97$ & $03 / 04 / 98$ \\
\hline End Date & 28/06/91 & & & & & & & \\
\hline dge Ratio & & & & & & & & \\
\hline EC sto & & & & & & & & \\
\hline & & & & & & & & \\
\hline R-squ & & & & & & & & \\
\hline Sk & & & & & & & & \\
\hline $\begin{array}{l}\text { Exce } \\
\text { Kurt }\end{array}$ & & -0.1687 & & & & & & \\
\hline $\begin{array}{r}\text { Durbin V } \\
\text { (p-valu }\end{array}$ & & & & & & & & \\
\hline $\begin{array}{c}\text { Jarque-Bera } \chi^{2} \\
\text { (p-value) }\end{array}$ & 0.9030 & & & & & $\begin{array}{c}0.61 \\
(0.737)\end{array}$ & & $\begin{array}{l}3.276 \\
(0.194)\end{array}$ \\
\hline $\begin{array}{l}\text { ARCH } \chi^{2} \\
\text { (p-value) }\end{array}$ & $\begin{array}{c}0.013 \\
(0.908)\end{array}$ & $\begin{array}{c}1.088 \\
(0.297)\end{array}$ & $\begin{array}{c}0.099 \\
(0.754)\end{array}$ & $\begin{array}{c}0.128 \\
(0.720)\end{array}$ & $\begin{array}{c}0.056 \\
(0.813)\end{array}$ & $\begin{array}{c}0.159 \\
(0.690)\end{array}$ & $\begin{array}{c}1.948 \\
(0.163)\end{array}$ & $\begin{array}{l}0.007 \\
(0.932)\end{array}$ \\
\hline
\end{tabular}

Hedge ratios are calculated over estimation periods of 60 days, assuming that futures roll-over occurs 5 days prior to expiry of the nearest futures contract. Results are estimated over eight distinct time periods, namely "Test Periods" 1 to 8 . All hedge ratios are statistically significant at the $1 \%$ level. The ARCH test is associated with 1 degree of freedom. The Jarque-Bera test is associated with 2 degrees of freedom. 
Table 3

Comparison of the Standard Deviations of Daily Returns on Hedged and Unhedged Portfolios, the Howard and D'Antonio (1987) HBS Measure and the Lindahl (1991) Mean and Standard Deviation Measures of Effectiveness of Hedge Ratios Across Different Estimation Period Lengths

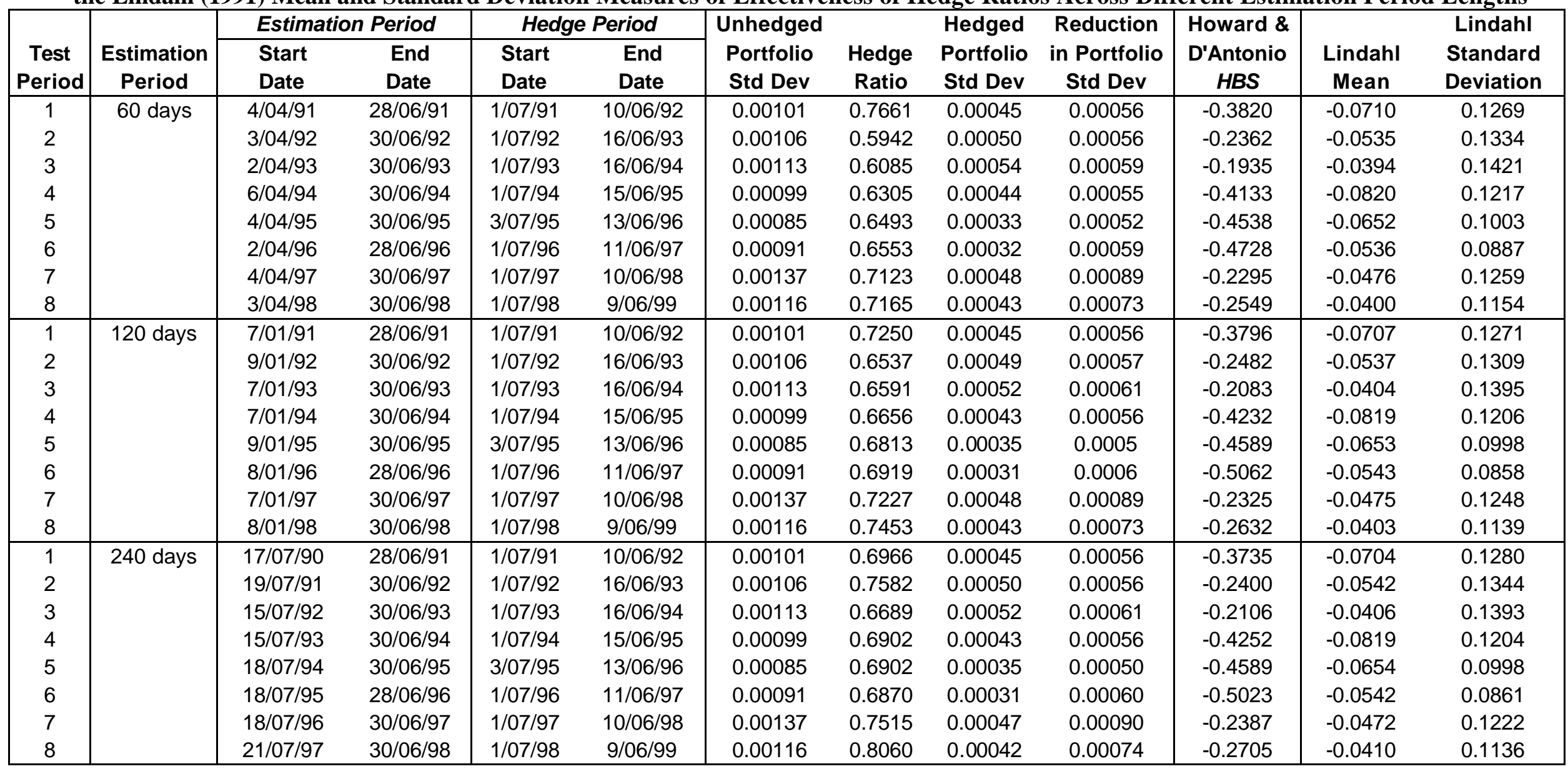

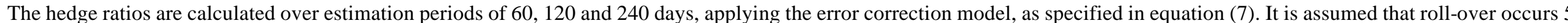
days to expiry of the nearest futures contract. The effectiveness of the hedge is determined over hedge periods of 240 days. 
Table 4

Rankings of Hedges Using the Reduction in Portfolio Standard Deviation Measure, the Howard and D'Antonio's (1987) HBS Effectiveness Measure, Lindahl's (1991) Mean and Standard Deviation Effectiveness Measure Across Different Estimation Period Lengths

\begin{tabular}{|c|c|c|c|c|c|c|c|c|c|c|c|c|c|c|}
\hline \multirow[b]{3}{*}{$\begin{array}{c}\text { Test } \\
\text { Period }\end{array}$} & \multirow{2}{*}{\multicolumn{2}{|c|}{ Hedge Period }} & \multirow{2}{*}{\multicolumn{3}{|c|}{$\begin{array}{c}\text { Portfolio Standard Deviation } \\
\text { Estimation Period } \\
\end{array}$}} & \multicolumn{3}{|c|}{ HBS } & \multirow{2}{*}{\multicolumn{3}{|c|}{$\begin{array}{c}\text { Lindahl Mean } \\
\text { Estimation Period }\end{array}$}} & \multirow{2}{*}{\multicolumn{3}{|c|}{$\begin{array}{c}\text { Lindahl Standard Deviation } \\
\text { Estimation Period }\end{array}$}} \\
\hline & & & & & & \multicolumn{3}{|c|}{ Estimation Period } & & & & & & \\
\hline & $\begin{array}{l}\text { Start } \\
\text { Date }\end{array}$ & $\begin{array}{l}\text { End } \\
\text { Date }\end{array}$ & $\begin{array}{c}60 \\
\text { days }\end{array}$ & $\begin{array}{c}120 \\
\text { days }\end{array}$ & $\begin{array}{c}240 \\
\text { days }\end{array}$ & $\begin{array}{c}60 \\
\text { days }\end{array}$ & $\begin{array}{c}120 \\
\text { Days }\end{array}$ & $\begin{array}{c}240 \\
\text { days }\end{array}$ & $\begin{array}{c}60 \\
\text { days }\end{array}$ & $\begin{array}{c}120 \\
\text { days }\end{array}$ & $\begin{array}{c}240 \\
\text { Days }\end{array}$ & $\begin{array}{c}60 \\
\text { days }\end{array}$ & $\begin{array}{c}120 \\
\text { days }\end{array}$ & $\begin{array}{c}240 \\
\text { days }\end{array}$ \\
\hline 1 & $1 / 07 / 91$ & $10 / 06 / 92$ & 1 & 1 & 1 & 3 & 2 & 1 & 3 & 2 & 1 & 1 & 2 & 3 \\
\hline 2 & $1 / 07 / 92$ & $16 / 06 / 93$ & 2 & 1 & 2 & 1 & 3 & 2 & 1 & 2 & 3 & 2 & 1 & 3 \\
\hline 3 & $1 / 07 / 93$ & $16 / 06 / 94$ & 3 & 1 & 1 & 1 & 2 & 3 & 1 & 2 & 3 & 3 & 2 & 1 \\
\hline 4 & $1 / 07 / 94$ & $15 / 06 / 95$ & 3 & 1 & 1 & 1 & 2 & 3 & 3 & 2 & 1 & 3 & 2 & 1 \\
\hline 5 & 3/07/95 & $13 / 06 / 96$ & 1 & 2 & 2 & 1 & 2 & 2 & 1 & 2 & 3 & 3 & 1 & 2 \\
\hline 6 & $1 / 07 / 96$ & $11 / 06 / 97$ & 3 & 1 & 1 & 1 & 3 & 2 & 1 & 3 & 2 & 3 & 1 & 2 \\
\hline 7 & $1 / 07 / 97$ & $10 / 06 / 98$ & 2 & 2 & 1 & 1 & 2 & 3 & 3 & 2 & 1 & 3 & 2 & 1 \\
\hline 8 & $1 / 07 / 98$ & 9/06/99 & 2 & 2 & 1 & 1 & 2 & 3 & 1 & 2 & 3 & 3 & 2 & 1 \\
\hline \multirow{2}{*}{\multicolumn{3}{|c|}{$\begin{array}{c}\text { Average Ranking } \\
\text { Overall Ranking }\end{array}$}} & 2.1 & 1.4 & 1.3 & 1.3 & 2.3 & 2.4 & 1.8 & 2.1 & 2.1 & 2.6 & 1.6 & 1.8 \\
\hline & & & 3 & 2 & 1 & 1 & 2 & 3 & 1 & 2 & 2 & 3 & 1 & 2 \\
\hline
\end{tabular}

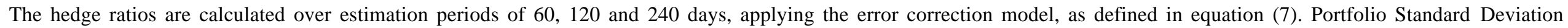

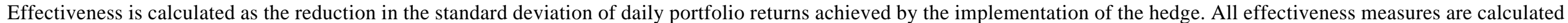

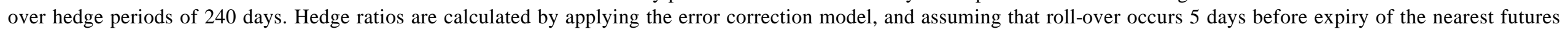
contract. Estimation periods are defined above in Table 3. 
Table 5

Rankings of Hedges Using the Portfolio Standard Deviation Measure, the Howard and D'Antonio's (1987) HBS Effectiveness Measure, the Lindahl (1991) Mean and Standard Deviation Measures of Effectiveness, over Hedge Periods of 5 days

\begin{tabular}{|c|c|c|c|c|c|c|c|c|c|c|c|c|c|c|}
\hline \multirow[b]{3}{*}{$\begin{array}{l}\text { Test } \\
\text { Period }\end{array}$} & \multirow{2}{*}{\multicolumn{2}{|c|}{ Hedge Period }} & \multirow{2}{*}{\multicolumn{3}{|c|}{$\begin{array}{c}\text { Portfolio Standard Deviation } \\
\text { Estimation Period }\end{array}$}} & \multicolumn{3}{|c|}{ HBS } & \multicolumn{3}{|c|}{ LindahI Mean } & \multirow{2}{*}{\multicolumn{3}{|c|}{$\frac{\text { Lindahl Standard Deviation }}{\text { Estimation Period }}$}} \\
\hline & & & & & & \multicolumn{3}{|c|}{ Estimation Period } & \multicolumn{3}{|c|}{ Estimation Period } & & & \\
\hline & $\begin{array}{l}\text { Start } \\
\text { Date }\end{array}$ & $\begin{array}{l}\text { End } \\
\text { Date }\end{array}$ & $\begin{array}{c}60 \\
\text { days }\end{array}$ & $\begin{array}{c}120 \\
\text { Days }\end{array}$ & $\begin{array}{l}240 \\
\text { days }\end{array}$ & $\begin{array}{c}60 \\
\text { Days }\end{array}$ & $\begin{array}{c}120 \\
\text { days }\end{array}$ & $\begin{array}{c}240 \\
\text { days }\end{array}$ & $\begin{array}{c}60 \\
\text { days }\end{array}$ & $\begin{array}{c}120 \\
\text { days }\end{array}$ & $\begin{array}{c}240 \\
\text { days }\end{array}$ & $\begin{array}{c}60 \\
\text { days }\end{array}$ & $\begin{array}{c}120 \\
\text { days }\end{array}$ & $\begin{array}{c}240 \\
\text { days }\end{array}$ \\
\hline 1 & $1 / 07 / 91$ & $5 / 07 / 91$ & 3 & 1 & 1 & 3 & 2 & 1 & 3 & 2 & 1 & 3 & 2 & 1 \\
\hline 2 & $1 / 07 / 92$ & $7 / 07 / 92$ & 2 & 2 & 1 & 1 & 2 & 3 & 1 & 2 & 3 & 2 & 1 & 3 \\
\hline 3 & $1 / 07 / 93$ & $7 / 07 / 93$ & 3 & 2 & 1 & 3 & 2 & 1 & 3 & 2 & 1 & 3 & 2 & 1 \\
\hline 4 & $1 / 07 / 94$ & $7 / 07 / 94$ & 3 & 2 & 1 & 1 & 2 & 3 & 3 & 2 & 1 & 3 & 2 & 1 \\
\hline 5 & 3/07/95 & $7 / 07 / 95$ & 1 & 2 & 2 & 1 & 3 & 2 & 1 & 2 & 3 & 3 & 2 & 1 \\
\hline 6 & $1 / 07 / 96$ & $5 / 07 / 96$ & 1 & 2 & 2 & 3 & 1 & 2 & 3 & 1 & 2 & 1 & 3 & 2 \\
\hline 7 & $1 / 07 / 97$ & $7 / 07 / 97$ & 2 & 2 & 1 & 1 & 2 & 3 & 3 & 2 & 1 & 3 & 2 & 1 \\
\hline 8 & 1/07/98 & 7/07/98 & 1 & 2 & 3 & 1 & 2 & 3 & 3 & 1 & 2 & 1 & 2 & 3 \\
\hline \multirow{2}{*}{\multicolumn{3}{|c|}{$\begin{array}{c}\text { Average Ranking } \\
\text { Overall Ranking }\end{array}$}} & 2 & 1.9 & 1.5 & 1.8 & 2 & 2.3 & 2.5 & 1.8 & 1.8 & 2.4 & 2 & 1.6 \\
\hline & & & 3 & 2 & 1 & 1 & 2 & 3 & 3 & 1 & 1 & 3 & 2 & 1 \\
\hline
\end{tabular}

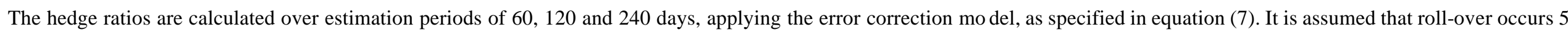
days to expiry of the nearest futures contract. Estimation periods are as defined in Table 3. 
Table 6

Determination of Whether Hedged Portfolios Provide Superior Performance to Unhedged Portfolios over Hedge Periods of 5 days and 240 days

\begin{tabular}{|c|c|c|c|c|c|c|c|c|}
\hline $\begin{array}{c}\text { Hedge } \\
\text { Period }\end{array}$ & $\begin{array}{c}\text { Test } \\
\text { Period }\end{array}$ & $\begin{array}{c}\text { Hedged } \\
\text { Portfolio } \\
\text { Daily } \\
\text { Return, } \mathbf{r}_{\mathrm{h}}\end{array}$ & $\begin{array}{c}\text { Unhedged } \\
\text { Portfolio } \\
\text { Daily } \\
\text { Return, } \mathbf{r}_{\mathbf{s}}\end{array}$ & $\begin{array}{c}\text { Risk-free } \\
\text { Rate, } \mathbf{i}\end{array}$ & $\mathbf{r}_{\mathrm{s}} \mathbf{i}$ & $\mathbf{\mathbf { r } _ { \mathrm { h } } \mathbf { i }}$ & HBS & $\begin{array}{c}\text { Hedged } \\
\text { Portfolio } \\
\text { outperforms } \\
\text { Unhedged? }\end{array}$ \\
\hline 5 & 1 & 0.00023 & 0.00054 & 0.00039 & $\mathrm{y}$ & $\mathrm{n}$ & -0.2920 & $\mathrm{n}$ \\
days & 2 & 0.00023 & 0.00026 & 0.00024 & $\mathrm{y}$ & $\mathrm{n}$ & -0.0611 & $\mathrm{n}$ \\
& 3 & 0.00036 & 0.00053 & 0.00020 & $\mathrm{y}$ & $\mathrm{y}$ & 0.0430 & $\mathrm{y}$ \\
& 4 & -0.00025 & -0.00036 & 0.00018 & $\mathrm{n}$ & $\mathrm{n}$ & -0.3748 & $\mathrm{n}$ \\
& 5 & -0.00003 & 0.00037 & 0.00028 & $\mathrm{y}$ & $\mathrm{n}$ & -1.6585 & $\mathrm{n}$ \\
& 6 & -0.00006 & -0.00013 & 0.00028 & $\mathrm{n}$ & $\mathrm{n}$ & -0.7173 & $\mathrm{n}$ \\
& 7 & -0.00001 & -0.00010 & 0.00021 & $\mathrm{n}$ & $\mathrm{n}$ & -0.1636 & $\mathrm{n}$ \\
\hline 240 & 8 & 0.00015 & 0.00094 & 0.00019 & $\mathrm{y}$ & $\mathrm{n}$ & -1.0143 & $\mathrm{n}$ \\
days & 1 & 0.00003 & 0.00006 & 0.00031 & $\mathrm{n}$ & $\mathrm{n}$ & -0.3735 & $\mathrm{n}$ \\
& 2 & 0.00002 & 0.00003 & 0.00023 & $\mathrm{n}$ & $\mathrm{n}$ & -0.2400 & $\mathrm{n}$ \\
& 3 & 0.00004 & 0.00009 & 0.00020 & $\mathrm{n}$ & $\mathrm{n}$ & -0.2106 & $\mathrm{n}$ \\
& 4 & -0.00001 & -0.00001 & 0.00032 & $\mathrm{n}$ & $\mathrm{n}$ & -0.4252 & $\mathrm{n}$ \\
& 5 & 0.00003 & 0.00005 & 0.00029 & $\mathrm{n}$ & $\mathrm{n}$ & -0.4589 & $\mathrm{n}$ \\
& 6 & 0.00003 & 0.00008 & 0.00025 & $\mathrm{n}$ & $\mathrm{n}$ & -0.5023 & $\mathrm{n}$ \\
& 7 & 0.00001 & -0.00003 & 0.00019 & $\mathrm{n}$ & $\mathrm{n}$ & -0.2387 & $\mathrm{n}$ \\
\hline
\end{tabular}

The hedge ratios are calculated over the estimation period of 240 days, using the error correction model as defined in equation (7), assuming a roll-over of 5 days to maturity. The 240 day estimation periods are defined in Table 3. The 5 day hedge periods are defined in Table 5. The 240 day hedge periods are defined in Table 4. $H B S$ refers to the Howard and D'Antonio (1987) measure of effectiveness. If the HBS is positive, the hedged portfolio "outperforms" the unhedged portfolio, given the risk-return trade-off. If the $H B S$ measure is zero, the hedged and unhedged portfolios perform equally. If $H B S$ is negative, the unhedged portfolio outperforms the hedged portfolio and the investor is disadvantaged by the hedge. 


\section{REFERENCES}

Anderson, R.W. and Danthine, J-P. 1981, “Cross Hedging”, Journal of Political Economy, vol.89, no.6, pp.1182-1196.

Benet, B.A. and Luft, C.F. 1995, "Hedge Performance of SPX Index Options and S\&P 500 Futures", Journal of Futures Markets, vol.15, no.6, pp.619-717.

Black, F. 1976, "The Pricing of Commodity Contracts", Journal of Financial Economics, vol.3, pp.167-179.

Castelino, M.G. 1992, "Hedge Effectiveness: Basis Risk and Minimum-Variance Hedging", Journal of Futures Markets, vol.12, no.2, pp.187-201.

Chang, J.S.K. and Shanker, L. 1987, "A Risk-Return Measure of Hedging Effectiveness: A Comment”, Journal of Financial and Quantitative Analysis, vol.22, no.3, pp.373-376.

Collins, B.M. and Fabozzi, F.J. 1999, "Derivatives and Risk Management", Journal of Portfolio Management Special Issue: Derivatives and Risk Management, Special Issue, pp.16-27.

Culp, C.L. and Miller, M.H. 1995, "Hedging in the Theory of Corporate Finance: A Reply to Our Critics", Journal of Applied Corporate Finance, vol.8, no.1, pp 121-127.

Dale, C. 1981, "The Hedging Effectiveness of Currency Futures Markets", Journal of Futures Markets, vol.1, no.1, pp.77-88.

de Jong, A., de Roon, F., and Veld, C. 1997, "Out-of-Sample Hedging Effectiveness of Currency Futures for Alternative Models and Hedging Strategies", Journal of Futures Markets, vol.17, no.7, pp.817-837.

Duffie, D. 1989, Futures Markets, Prentice-Hall Inc, New Jersey.

Ederington, L.H. 1979, "The Hedging Performance of the New Futures Markets", Journal of Finance, vol.34, no.1, pp.157-170.

Edwards, F.R. and Canter, M.S. 1995, "The Collapse of Metallgesellschaft: Unhedgeable Risks, Poor Hedging Strategy or Just Bad Luck?", Journal of Futures Markets, vol.15, no.3, pp.211-264.

Engle, R.F. and Granger, C.W.J. 1987, "Co-Integration and Error Correction: Representation, Estimation and Testing", Econometrica, vol.55, no.2, pp.251-276.

Franckle, C.T. 1980, "The Hedging Performance of the New Futures Markets: Comment", Journal of Finance, vol.35, no.5, pp.1273-1279.

Ghosh, A. 1993a, "Cointegration and Error Correction Models: Intertemporal Causality Between Index and Futures Prices", Journal of Futures Markets, vol.13, no.2, pp.193-198.

Ghosh, A. 1993b, "Hedging with Stock Index Futures: Estimation and Forecasting with Error Correction Model", Journal of Futures Markets, vol.13, no.7, pp.743-752.

Gjerde, $\varnothing .1987$, "Measuring Hedging Effectiveness in a Traditional One-Periodic Portfolio Framework", Journal of Futures Markets, vol.7, no.6, pp.663-674. 
Herbst, A.F., Kare, D.D. and Caples, S.C. 1989, "Hedging Effectiveness and Minimum Risk Hedge Ratios in the Presence of Autocorrelation: Foreign Currency Futures", Journal of Futures Markets, vol.9, no.3, pp.185-197.

Hill, J. and Schneeweis, T. 1981, "A Note on the Hedging Effectiveness of Foreign Currency Futures”, Journal of Futures Markets, vol.1, no.4, pp.659-664.

Howard, C.T. and D'Antonio, L.J. 1984, “A Risk-Return Measure of Hedging Effectiveness", Journal of Financial and Quantitative Analysis, vol.19, no.1, pp.101-112.

Howard, C.T. and D’Antonio, L.J. 1987, “A Risk-Return Measure of Hedging Effectiveness: A Reply”, Journal of Financial and Quantitative Analysis, vol.22, no.3, pp.377-381.

Hsin, C-W., Kuo, J. and Lee, C-F. 1994, “A New Measure to Compare the Hedging Effectiveness of Foreign Currency Futures Versus Options”, Journal of Futures Markets, vol.14, no.6, pp.685707.

Hull, J.C. 1997, Options, Futures, and Other Derivatives (3rd edn), Prentice Hall International Inc., New Jersey.

Johnson, L.L. 1960, "The Theory of Hedging and Speculation in Commodity Futures", Review of Economic Studies, vol.27, no.74, pp.139-151.

Kolb, R.W. and Okunev, J. 1993, "Utility Maximising Hedge Ratios in the Extended Mean Gini Framework", Journal of Futures Markets, vol.13, no.6, pp.597-609.

Kroner, K.F. and Sultan, J. 1993, "Time-Varying Distributions and Dynamic Hedging with Foreign Currency Futures", Journal of Financial and Quantitative Analysis, vol.28, no.4, pp.535-551.

Kuo, C-K. and Chen, K-W. 1995, "A Risk-Return Measure of Hedging Effectiveness: A Simplification", Journal of Futures Markets, vol.15, no.1, pp.39-44.

Lien, D. and Luo, X. 1993, "Estimating Multiperiod Hedge Ratios in Cointegrated Markets", Journal of Futures Markets, vol.13, no.8, pp.909-920.

Lien, D. and Shaffer, D.R. 1999, "A Note on Estimating the Minimum Extended Gini Hedge Ratio", Journal of Futures Markets, vol.19, no.1, pp.101-113.

Lindahl, M. 1991, "Risk-Return Hedging Effectiveness Measures for Stock Index Futures", Journal of Futures Markets, vol.11, no.4, pp.399-409.

Markowitz, H.M. 1959, Portfolio Selection: Efficient Diversification of Investments, John Wiley and Sons, Inc., New York.

Marshall, J.F. and Herbst, A.F. 1992, "A Multiperiod Model for the Selection of a Futures Portfolio", Journal of Futures Markets, vol.12, no.4, pp.411-428.

Mian, S.L. 1996, "Evidence on Corporate Hedging Policy", Journal of Financial and Quantitative Analysis, vol.31, no.3, pp.419-439.

Nance, D.R., Smith, C.W., and Smithson, C.W. 1993, "On the Determinants of Corporate Hedging”, Journal of Finance, vol.48, no.1, pp.267-284. 
Park, T.H. and Switzer, L.N. 1995, "Bivariate GARCH Estimation of the Optimal Hedge Ratios for Stock Index Futures Contracts", Journal of Futures Markets, vol.15, no.1, pp.61-67.

Pennings, J.M.E. and Meulenberg, M.T.G. 1997, "Hedging Efficiency: A Futures Exchange Management Approach", Journal of Futures Markets, vol.17, no.5, pp.599-615.

Pirrong, S.C. 1997, "Metallgesellschaft: A Prudent Hedger Ruined, or a Wildcatter on NYMEX?", Journal of Futures Markets, vol.17, no.5, pp.543-578.

Pizzi, M.A., Economopoulos, A.J., and O’Neill, H.M. 1998, “An Examination of the Relationship Between Stock Index Cash and Futures Markets: A Cointegration Approach", Journal of Futures Markets, vol.18, no.3, pp.297-305.

Reserve Bank of Australia 1999, Reserve Bank of Australia Bulletin September 1999.

Satyanarayan, S. 1998, “A Note on a Risk-Return Measure of Hedging Effectiveness", Journal of Futures Markets, vol.18, no.7, pp.867-870.

Shalit, H. 1995, "Mean-Gini Hedging in Futures Markets", Journal of Futures Markets, vol.15, no.6, pp.617-635.

Sharpe, W.F. 1994, “The Sharpe Ratio”, Journal of Portfolio Management, vol.21, pp.49-58.

Smith, C.W., Smithson, C.W., and Wilford, D.S. 1990, Managing Financial Risk, Harper Collins Publishers, New York.

Smith, C.W. and Stulz, R.M. 1985, “The Determinants of Firms' Hedging Policies”, Journal of Financial and Quantitative Analysis, vol.20, no.4, pp.391-405.

Stein, J.L. 1961, "The Simultaneous Determination of Spot and Futures Prices", American Economic Review, vol.51, no.5, pp.1012-1025.

Stoll, H.R. and Whaley, R.E. 1990, "The Dynamics of Stock Index and Stock Index Futures Returns", Journal of Financial and Quantitative Analysis, vol.25, no.4, pp.441-468.

Sutcliffe, C.M.S. 1993, Stock Index Futures: Theories and International Evidence, Chapman and Hall, London.

Wahab, M. and Lashgari, M. 1993, "Price Dynamics and Error Correction in Stock Index and Stock Index Futures Markets: A Cointegration Approach", Journal of Futures Markets, vol.13, no.7, pp.711-742.

Walter, I. 1999, "The Global Asset Management Industry: Competitive Structure and Performance", Financial Markets, Institutions and Instruments, vol.8, no.1, pp.1-78.

Working, H. 1953, "Futures Trading and Hedging", American Economic Review, vol.43, no.3, pp.314-343.

Working, H. 1962, "New Concepts Concerning Futures Markets and Prices", American Economic Review, vol.52, no.3, pp.431-459. 